\title{
HISTORY
}

\section{THE CONTRIBUTION OF MYKOLA SUMTZOV IN THE STUDY OF ALEXANDR PUSHKIN LEGACY (BASED ON KHARKIV MATERIALS)}

\author{
Ivanova Karina Andriivna, D.Sc. in Philosophy, professor, head of Philosophy and Sociology \\ Department, National University of Pharmacy, Kharkiv, Ukraine \\ ORCID: https://orcid.org/0000-0003-1852-4809
}

Khirina Anna Oleksandrivna, Ph.D. in History, associate professor of Philosophy and Sociology Department, National University of Pharmacy, Kharkiv, Ukraine

ORCID: https://orcid.org/0000-0003-1293-8189

Balabay Yana Volodymyrivna, Ph.D. in History, associate professor of Philosophy and Sociology Department, National University of Pharmacy, Kharkiv, Ukraine

\section{DOI: https://doi.org/10.31435/rsglobal_ws/31052020/7084}

\section{ARTICLE INFO}

Received: 15 March 2020

Accepted: 19 May 2020

Published: 31 May 2020

\section{KEYWORDS}

Mykola Sumtzov,

Alexandr Pushkin,

Kharkiv,

poetry,

culture.

\begin{abstract}
The article is devoted to the one of the most outstanding scientists of Kharkiv University of the late $19^{\text {th }}$ - early $20^{\text {th }}$ centuries - professor of The History and Philology Faculty of Kharkiv University Mykola Sumtzov. The authors paid attention to the contribution of Mykola Sumtzov in the study of Alexandr Pushkin poetry and his activities to memorialize of poet's personality in the city of Kharkiv. Mykola Sumtzov's study of the most famous poetry of Pushkin are analyzed in the article. Sumtzov reviewed and analyzed Pushkin poems in detail, searched for analogues and parallels with the works of other authors. He took interest in creative conditions of the poet, in his special style and in his rich spirituality. Mykola Sumtzov as the most devoted admirer made great efforts to commemorate Alexander Pushkin in Kharkiv. He understood an outstanding importance of Pushkin's poetry in the development of culture. Sumtzov wrote that in the conditions of early $20^{\text {th }}$ century Russian Empire reality only free culture would promote the development of flourishing Ukrainian culture.
\end{abstract}

Citation: Ivanova K. A., Khirina A. O., Balabay Y. V. (2020) The Contribution of Mykola Sumtzov in the Study of Alexandr Pushkin Legacy (Based on Kharkiv Materials). World Science. 5(57), Vol.3. doi: 10.31435/rsglobal_ws/31052020/7084

Copyright: (C) 2020 Ivanova K. A., Khirina A. O., Balabay Y. V. This is an open-access article distributed under the terms of the Creative Commons Attribution License (CC BY). The use, distribution or reproduction in other forums is permitted, provided the original author(s) or licensor are credited and that the original publication in this journal is cited, in accordance with accepted academic practice. No use, distribution or reproduction is permitted which does not comply with these terms.

Introduction. Studies of Pushkin's poetic legacy in the world are vast, thousands of research papers devoted to his life and works are published and the new studies appear every year. It looks like all the poet's works have been analyzed and all the pages of his biography are thoroughly studied. There is one poorly researched page in the history of the tribute to the memory of the great poet. And that page is connected to the city of Kharkiv and to one of its greatest citizens, professor of Kharkiv University and member of Russian, Ukrainian and Czech Academies of Science, an outstanding public figure and the author of more then 1500 scientific works - Sumtzov Mykola Fedorovytch (1854 1922). The works and public activity of Mykola Sumtzov dealt with all the various sides of life of the city of Kharkiv in the second half of the $19^{\text {th }}$ century. But there was one theme reflected both in the scientific work and in the public activity of the scientist. That theme was Pushkin. Traditionally the researchers of Sumtzov's works paid more attention to Ukrainian theme in his activities and works. 
The topic of Pushkin's legacy was one of the most important for Sumtzov. Being a patriot of the Ukrainian nation at the same time Sumtzov is an example of multicultural essence of Ukrainian intellectuals of the $19^{\text {th }}$ century. Sumtzov studies of Pushkin, the history of the poet's attitude towards Kharkiv, the long history of the Pushkin monument in the city, commemoration of the poet in the city, popularization of his poetry, revolutionary events in Kharkov at the beginning of the $20^{\text {th }}$ century, the rise of national movement - is a long list of events and opinions ambiguous even today. Scientific interest to Pushkin emerged in Kharkiv largely due to activities and writings of Mykola Sumtzov. Sumtzov was the most devoted admirer and propagandist of many outstanding writers. Pushkin was his favorite poet, whose works mainly influenced the scientist's tastes in literature.

Research results. Many researchers in Kharkov believe that Pushkin legacy promotion started in 1899 in connection with his centennial anniversary. But professor Sumtzov got interested in Pushkin as a cultural phenomenon earlier, and from 1878 since 1922 he published 34 scientific articles about Pushkin. That was unsurprising, as Sumtzov since his childhood was a true lover, admirer and connoisseur of poetry, and was brought up with Pushkin poetry, knowing much by heart. So his scientific interest to works of Pushkin was natural. Sumtzov reviewed and analyzed Pushkin poems in detail, searched for analogues and parallels with the works of other authors. He took interest in creative laboratory of the poet, in his style and in his rich spirituality. Sumtzov rated Pushkin as property of the world culture, rather than only of Russian culture, and thought it was necessary to popularize his works among the youth.

All Sumtzov writings on Pushkin can be divided into two groups: the first group represented by thoughtful literary criticism of the poet's works - "Essays on Pushkin" (1893 - 1897) [15 - 21], "Studies of Pushkin poetry" (1900) [6], "On Pushkin poem "A worn out traveler cursed his own God" (1893) [10], "The Miserly Knight, "Female Legs" in Pushkin poems"// "Petty remarks on A. Pushkin and his poems" (1900) [13], "Pushkin and Tyutchev" (1900) [1], "V. A. Zhukovsky and A. S. Pushkin" (1902) [4], "Pushkin about Erzerum" (1916) [3], "Pushkin and Shevtchenko" (1917) [2].

The second group includes newspaper and magazine publications on certain fragments of the poet's life, on commemoration of Pushkin in Kharkiv. Sumtzov studies were rarely republished, the republished ones are mainly of ethnography content, so modern reader is practically ignorant of scientific legacy of this unique scientist regarding A. Pushkin.

Mykola Sumtzov deeply felt the mood, the change of the poet's soul, he accomplished the most thorough analysis of the texts of Pushkin poems. "Essays on Pushkin" is a series of works in five issues written and published first in a specialized magazine "Russian Philological Bulletin" and then as separate publications in Warsaw during 1893 - 1897, amounting all to 394 pages. In 1900 Sumtzov published in Kharkiv another work of 350 pages titled "Studies of Pushkin's poetry" included a lot of materials from his "Essays on Pushkin" [15-21].

In his "Essays on Pushkin" [15 - 21] Sumtzov accomplished analysis of more than 50 poems by Pushkin. What was of interest for Sumtzov in Pushkin's verses? We think that Sumtzov sought for parallels with folk poetry, not only with Ukrainian one, but also with English, Scottish, Italian, French and German ones. Being fluent in many languages (Sumtzov knew perfect German, French, Italian, English, Classical Greek, Latin, Sanskrit), the scientist looked for semblance of plots, characters, locutions, sentiments in writings of European authors of the $12^{\text {th }}-19^{\text {th }}$ centuries. At the beginning of each article Sumtzov gives the full original text of a verse by Pushkin and then tries to find and cite in the original what was the source that inspired the poet to write in such way, and then analyzes every phrase of the verse in detail. Sumtzov also deals with critique of Pushkin's works in detail, actively arguing with other researchers of the poet's works. The scientist pays special attention to the poet's sentiments and how they are reflected in the contents. It is amazing how deep is Sumtzov's knowledge of the tiniest details of Pushkin's biography, his meetings with the other people. Sumtzov sensed Pushkin very deeply and acutely, always striving to explain the verses by the poet's sentiments, his antinomic moods. Thus, analyzing Pushkin's poem "Prophet" Sumtzov writes: "Immediately taking Pushkin's personality it should be mentioned that the metamorphosis of the prophet is a poetical picture or embodiment in one character of those incarnations of Pushkin's personal features which are revealed by thorough study of his life and his poetry. In Pushkin's personality two identities went along together - a passionate character with violent and vicious inclinations, and a character of high morality, with a deep penetrating mind and a heart open to everything good and beautiful. Pushkin was a very straight and open-hearted man, repugnant to any grand-standing" [20, 7]. 
In the work "Pushkin and Tyutchev" [1] Sumtzov not only investigates influence of Pushkin on the works of Tyutchev but rather analyzes Pushkin himself: "In poems by Tyutchev there lies that same attribute of history which defines and differs the poetry of that epoch. Tyutchev's verses represent the same inner sincerity and necessity that we can see as an attribute of earlier (pushkinian) poetic epoch. The sincerity should not be regarded as an exclusive attribute of history of pushkinian epoch. This virtue is personal but is not a public one and Pushkin had this personal feature. In opposite Tyutchev had something artificial and conformed, because of "demands" that were claimed by his friends "slavophils". Pushkin was a highly educated and well-read man. Moreover, he possessed an extraordinary gift of divination: he was able to divine the world's esthetic perceptions, he could penetrate the mysteries of history" - noted Sumtzov [1, 10]. Depicting the poet's attitude to life, Mykola Sumtzov reached the conclusion: "Pushkin often speaks about death but always in such a tone that his love of life gets even more emphasized" [1,9].

In some of his works Sumtzov analyzes the influence of Pushkin on other poets such as V. Zhukovsky [4], F. Tyutchev [1], T. Shevtchenko [2], comparing their artistic methods, stories and sentiments. Not all the researchers always agreed with Sumtzov's assessments but none of them remained uninterested. Sumtzov's works always stirred scientific discussions.

The other group of works about Pushkin includes brief articles in Kharkov press (newspapers "Kharkov", "Kharkovskie Vedomosti", "Yuzhny Krai"), such as "On the $50^{\text {th }}$ year since the day of death of Pushkin" [12], "Program of readings by prof. Sumtzov about A. S. Pushkin (for the article "Scientific readings for women")" [19], "On the date of 26 of May: the great day of ground breaking for construction of city college named after Pushkin on the day of the $100^{\text {th }}$ anniversary of the poet's birth" [9], "Preparing for Pushkin festivities: on the necessity for mass printing of a collection of selected works by A. Pushkin" [8], "On a literature-and-music morning session for students devoted to Pushkin in city schools and primary colleges on 27 of May" [11], "City parochial school in commemoration of A. Pushkin. Speech for consecration of building of Pushkin school on the $21^{\text {st }}$ of November [5], "On installation of a bust of Pushkin on Teatralnaya square" [7]. Even the titles of the abovementioned Sumtzov's articles show how much the scientist did for commemoration of his favorite poet. In these publications, which were read and actively discussed by readers in the city many of whom disliked the articles, Sumtzov promoted the work of the great poet and insisted on perpetuating the memory of the poet in Kharkiv. It was successful. Popularization of Pushkin's works revealed vast erudition and open-mindedness of Sumtzov who understood outstanding importance of Pushkin's work in the development of Russian culture. Sumtzov said and wrote that only free Russian culture would promote the development of flourishing Ukrainian culture. Sumtzov's lectures and publications about the life and work of Pushkin encouraged the interest of Kharkiv public opinion to the poet's personality and poems. Sumtzov knew that Pushkin never came to Kharkiv, he had strained relations with Vasyl Karazin - the founder of Kharkiv University and Pushkin made rather scornful remarks about the university. About his intention of visiting Kharkiv on his way to Caucasus in summer of 1829 the poet wrote in "A Journey to Arzrum" (1835): "I was to go via Kursk and Kharkov but I made a turn to go by direct road to Tiflis, sacrificing a good dinner in a Kursk inn (which is not a trifle in our travels) as I was not curious enough to visit Kharkov university which is not even a match for a tavern in Kursk". When Sumtzov cited this piece he always stressed that compared to enormous Pushkin's tribute to Russian culture his low grading of Kharkiv university of the first half of the $19^{\text {th }}$ century did not undermine the status of the city and of the university, but to pay homage to memory of Pushkin would be a great honor for Kharkiv though the poet never visited it.

According to Sumtzov's initiative on the 26 of May, 1898 the ground was broken for construction of a new educational institution - a parochial college named after Pushkin, and on the 21 November 1901 it was commissioned. Mykola Sumtzov invested a considerable amount of his own funds in this construction and became a trustee of the college. Pushkin's college was one of the best educational institutions of that time in quality of teaching and in applying new teaching methods. Pushkin college became the best memorial of the poet and the dearest creation for Sumtzov.

Due to the approaching date of the $100^{\text {th }}$ Pushkin anniversary the question about monument to Pushkin was actively discussed in Kharkiv. Mykola Sumtzov was one of initiators for placing a monument of the poet on Teatralna square, he gave public lectures about Pushkin, he spoke much at sessions of local city council and its committees. It was a difficult question because of perception of Pushkin as an embodiment of Russian culture was ambiguous among Kharkov public. Members of 
city council broke into "Ukrainophils" and "Russophils". And while "Russophils" fully supported the policy of Peterburg authorities and campaigned for building of the monument, "Ukrainophils" started to struggle against imposition of Russian culture in Ukraine and campaigned against the monument to the Russian poet. Sumtzov strived to pacify these two camps, explained the importance of having monument to Pushkin in Kharkiv for the development of the city and for its cultural image.

Long debates in Kharkiv City Council during 1897 - 1898 did not solve the question about building of the monument. In October 1900 mayor of the city Ivan Golenischev-Kutuzov who couldn't dare to permit the monument was replaced by new head of city council - professor of physics of Kharkov Technology Institute Alexander Pogorelko who was an educated and progressive man and a good friend of Sumtzov. Mykola Sumtzov was elected as a member of Kharkov City Council. So the question of installation of a Pushkin monument came on the agenda again. Alexander Pogorelko and Kharkiv City Council with members -professors of Kharkiv University dealt with urban refurbishment, stood for the principles of self-government and democratization of governing the city, worked-out and accomplished a comprehensive program for urban refurbishment and development according to Western European model and tried to enhance the city's cultural image. So it wasn't surprising that Kharkiv City Council decided to reconsider the question of the monument to Pushkin and set up a special commission for supervising the process of work on the monument. The commission established recommendations a bronze bust on a granite tomb. The overall cost of the monument was 2 thousand 338 roubles, though Sumtzov in his article "On installation of Pushkin bust on Teatralna square" published 15 January 1904 in newspaper "Yuzhny Krai" put the costs of 2500 roubles [7], and generally favored the monument.

The gala-unveiling of the monument took place on the 26 of May 1904, on the poet's birthday. Kharkiv held festivities devoted to unveiling the memorial bust of Alexander Pushkin. Newspapers "Kharkovskie gubernskie vedomosti" and "Yuzhny Krai" reported that the order of celebrations was approved by City Council and negotiated with the governor. The City Council regarding the confrontations and discussions about the monument decided not to have any speeches when it was unveiled. The ceremony attracted lots of people: university professors and students, intelligentsia, gymnasium pupils and everybody who loved the poet's works. Though it was cloudy and rainy the celebrations went well. There was a music performance on Teatralna square by military brass band of $202^{\text {nd }}$ infantry reserve regiment, combined choir of students of Pushkin parochial city college, big choir of actors of Kharkov theatres. It was followed by public prayer accompanied by singing of big choir. At the monument there was a beautiful flower on the one side presented an image of lira and on the other side - an emblem of Kharkiv, all made-up with planted flowers.

Conclusions. Interest to Pushkin in Kharkiv arose in the middle of the 19th century, largely thanks to the activities and research of the academician, professor of The History and Philology Faculty of Kharkiv University Mykola Fedorovych Sumtzov (1854 - 1922). A native of the old Cossack Ukrainian family, born in St. Petersburg, Mykola Sumtzov is a striking example of the multiculturalism of the Ukrainian intelligentsia of the 19th century. An outstanding scientist stood at the origins of the national-cultural revival in Slobids'ka Ukraine, the Ukrainian national idea was crystallized in his writings, but at the same time, Mykola Sumtsov was the most devoted admirer and propagandist of the talent of many prominent Russian writers. Pushkin was his favorite poet, on whose work in many ways literary predilections of the scientist were formed.

\section{REFERENCES}

1. Сумцов Н. Ф. А. С. Пушкин и Ф. И. Тютчев. $1900 ; 19$.

2. Сумцов Н. Ф. А. С. Пушкин и Шевченко. Украинская жизнь. 1917; 3-6; 84-88.

3. Сумцов Н. Ф. А. С. Пушкин об Эрзеруме. Южный Край. 1916. 5.02.

4. Сумцов Н. Ф. В. А. Жуковский и А. С. Пушкин. Южсный Край. 1902. 12.04.

5. Сумцов Н.Ф. Городское приходское училище в память А.С. Пушкина. Речь пред. гор. училищ. комис. проф. Н.Ф. Сумцова при освящении здания Пушкинской школы 21 ноября. Южный Край. 1901. 24.11.

6. Сумцов Н. Ф. Исследования о поэзии Пушкина // Харьковский университетский сборник: В память А.С. Пушкина (1799-1899). 1900; 350.

7. Сумцов Н.Ф. К постановке бюста А.С.Пушкина на Театральной площади. Южный Край. 1904. 15.01.

8. Сумцов Н.Ф. К Пушкинским дням: О необходимости издать большим тиражом сб. избр. произведений А.С. Пушкина. Харьковские Губернские Ведомости. 1899. 22.01.

9. Сумцов Н.Ф. К 26 мая: О торжественной закладке городского училища им. А.С. Пушкина в день 100-летия со дня рождения поэта. Харьковские Губернские Ведомости. 1899. 26.05. 
10. Сумцов Н.Ф. О стихотворении А. С. Пушкина «И путник усталый на бога роптал / Tpyдbl Педагогического отдела Историко-филологического Общества. 1893:1; 11.

11. Сумцов Н.Ф. Об ученическом литературно-музыкальном утре в честь А.С. Пушкина 27 мая 1899 г. (в драматическом театре для учеников городских школ и начальных училищ). Харьковские Губернские Ведомости. 1899. 1.

12. Сумцов Н.Ф. По поводу 50-летия со дня смерти А.С. Пушкина. Харьковские Губернские Ведомости. 1887. 29.01.

13. Сумцов Н. Ф. «Скупой рыцарь»; «Женская ножка» в стихотворениях Пушкина: Мелкие заметки об А.С.Пушкине и его произведениях. Русская Старина. 1899: 98; 334-336.

14. Сумцов Н. Ф. Этюды об А. С. Пушкине. Русский филологический вестник. 1893:29; 1;148-163; 2; 353-382; 30; 3; 158-173; 4; 328-339.

15. Сумцов Н. Ф. Этюды об А. С. Пушкине. 1-2; 1893; 81 с.

16. Сумцов Н. Ф. Этюды об А. С. Пушкине. Русский филологический вестник.1894:3; 1-2; 269-304; 32:3; $45-76 ; 4 ; 155-174$.

17. Сумцов Н. Ф. Этюды об А. С. Пушкине. Вып. III. 1895; 87.

18. Сумцов Н. Ф. Программа чтений проф. Н. Ф. Сумцова об А. С. Пушкине (к статье «Научные чтения для женщин»). СХИФО. 1896:8; 30.

19. Сумцов Н. Ф. Этюды об А. С. Пушкине. Вып. І. 1896; 62.

20. Сумцов Н. Ф. Этюды об А. С. Пушкине. Указ. К I-V вып. «Этюдов об А. С. Пушкине». Русский филологический вестник.1897: 37: 1-2; 65-69, 71-93; 38: 3-4; 35-59.

21. Сумцов Н. Ф. Этюды об А. С. Пушкине. Вып.V. 1897; 69. 